\title{
Food Ontology Model for a Healthcare Service ${ }^{\dagger}$
}

\section{(헬스케어 서비스를 위한 푸드 온톨로지 모델)}

\author{
이 병 문
}

(Byung Mun Lee)

\begin{abstract}
요 약 유비쿼터스 정보기술이 의료서비스와 융합되면서 자가 건강관리에 필요한 다양한 형 태의 콘텐츠에도 영향을 주고 있다. 특히 웹과 모바일 환경의 빠른 변화로 다량의 헬스케어 콘 텐츠가 예상되기 때문에 검색의 효율성이 중요하다. 더구나 콘텐츠의 개인 맞춤형은 더 세밀하 고 필요하며 단순한 키워드 중심의 검색방식에서도 환자 또는 사용자 요구와 특성에 맞도록 효 율적인 검색방식이 필요하다. 따라서 콘텐츠의 의미를 시스템이 빠르게 이해할 수 있도록 정확한 시맨틱 검색이 필요하며 이를 위한 헬스케어 온톨로지를 모델링은 매우 의미 있다. 따라서 본 연 구에서는 Protege 툴을 활용하여 헬스케어 콘텐츠 중 음식(Food) 클래스와 하위 클래스를 설계 하고 각 클래스에 대한 제약조건 및 관계를 정의하여 실제 시스템에서 활용할 수 있는 시스템도 모델링하였다. 이렇게 모델링된 헬스케어 콘텐츠 온톨로지는 환자나 사용자들에게 원하는 정보 를 신속하고 정확하게 검색할 수 있는 기반을 제공해준다.
\end{abstract}

핵심주제어 : 헬스케어, 온톨로지, 푸드, 시멘틱

Abstract Ubiquitous technology influences on various firms of contents needed for self-healthcare, as it fuses into medical services. Particularly, rapid changes in the web and mobile environment, requiring various sorts of healthcare and its related contents, make efficiency of search more important. Personalized contents needs to be more refined as well as the existing simple keyword-centered searching method needs to be more effective in order to meet both requirements and characteristics of each patient or each user. A precise semantic searching method is required for a system to understand promptly the meaning of a contents. In this respect, to build a healthcare ontology has its own significance. This study builds up a system model that can be utilized practically in existing systems by setting up the Food Class and its sub-class among the healthcare contents with Protege tool and then materializing constraints and its relationships between each class. The healthcare contents ontology provides patients or users with a platform which can search the needed information promptly and precisely.

Key Words : Healthcare, Ontology, Food, Semantic

\section{Introduction}

\footnotetext{
† 이 논문은 2012년도 가천대학교 교내연구비 지원에 의해서 수 행된 결과임 (GCU-2012-R166).

* 가천대학교 인터랙티브미디어학과(bmlee@gachon.ac.kr)
}

Recently, the u-Health field requires an advanced form of healthcare service that supports those professional medical service and ubiquitous environment. For the self-healthcare service evolved to this extent, a personalized contents should be 
provided steadily and a positive care should be followed through feedback, and a function to recommend self-checkout and educational contents is required. While many researches and studies are enthusiastically under way to get rid of constraints of space and time by utilizing the ubiquitous technology that can access a network freely at any time from any place for those specialized medical information and services available only at the hospitals, steady healthcare service and preventive care-$^{-}$service in a regular and effective manner on a patient is required as the result from the aging society.

A huge amount of contents is now being produced and serviced thanks to the trend that distribution of contents and information is widely spreading out through various channels under such an environment, However, the existing keywordbased searching system can not provide patients, his/her family, and the other users with proper details in a speedy and correct manner, and sometimes, it may deliver improper outcome. Since a mechanical system can not understand most of internet information that can be understood only by human being due to it was generated in web document, a static document, or only its physical structure was described in metadata, users can not retrieve the exact information that needed and simply deliver fragmented data, unnecessary information or improper outcome[1].

The Semantic search is the technology enables a system to understand the meaning of contents and data and make a speedy and precise search for it not being confined to such a keyword searching method. One of the semantic search methods is modeling the ontology for the objects[2]. Therefore, this paper aims to study on ontology and the Semantic search for a solution of such a problem and to build up Food ontology among needed healthcare contents based on Protege order to provide patients and those related users with exact contents.

\section{Related Research}

\subsection{Semantic Web}

The existing Internet already has reached at the limit caused by information overload, it should be solved out in whatever forms. The only solution is to access information through a semantic approach. And, in respect of the quantity of information on the Internet, information should be processed, integrated, and provided in the form that a user want with a system semantically based. It is not easy to develop a machine capable to solve this sort of problems, however, it is the semantic web that has the highest probability of its realization at the present.

The Semantic Web is a framework enables a computer to process and describe relationships between resources and information on resources(Web documents, various files, and service, etc) in an ontology form under the divergence environment like the current Internet and enables an automated machine to process them[3].

While the natural language process or the artificial intelligence is assuming a technology that solves semantic ambiguity problem, the Semantic Web won't have semantic process problems, like the obstacles in the natural language process or artificial intelligence as it only targets the information sources that has no semantic ambiguity which has been eliminated by human being and other information sources[4].

The terms and conceptualization related to the Semantic Web vary by the application purpose, the application field, and the user who conceptualizes[5]. When considering the open characteristics of internet, accepting all of such a divergence would make it very difficult to control. For this reason, the Semantic Web assumes conceptualization using common ontology. Ontology in the Semantic Web means a vocabulary to be used in a specific field. It is realized by a name space. The vocabularies used 
in ontology can be systemized in many methods, and the easiest method is the thesaurus type of systemization by 'is-a' relationship[6]. Besides, the relationship between vocabularies also can be defined by other methods like 'part-of'. A language to be conceptualized in order to describe an information is RDF(Resource Description Framework), and the method to assure semantic entirety by imposing a type to RDF is RDF Schema. RDF describes knowledge with 3 elements(Triple, Property, and Value), since it is the most common and the simplest structure to describe knowledge[7].

\subsection{Ontology and Ontology Tools}

Ontology is a model conceptualizing a compromise through debates on what people see, hear, feel, and think ,and then describing it a type that computer can process. It is a technology to specifically define types of concepts or constraints in practical usage.

Ontology, describing a once compromised knowledge, is the concept that all members of a group agreed, not limited to an individual person[1]. Ontology enables human being and computer to understand concepts and to draw out the related meanings by defining concepts clearly and formatting the relationship between concepts.

For a language to construct ontology, RDF \& OWL were established as an international standard and are mostly used. And, the ontology tools based on these languages were also developed, like Protege, KAON, OILEd, OntoEdit, OWL Editor, and graphic editor[8]. Protege, an ontology tool, is developed by the Stanford University in U.S.A., and is now being mostly used for constructing ontology.

With a tree structure, it can be possible to materialize hierarchies of resources and to easily recognize information on resources, and to edit them[9]. KAON, jointly developed by Karlsruhe University in Germany and FZI Research Institute based on Web. Many users can access simultaneously, and then generate and modify
Ontology by setting ontology on a Server[10]. OILEd, a simple ontology editor developed by Manchester University based on DAML+OIL language, has an easily composed interface compared with other ontology tools. The Main Function of OILEd enables us to analyze ontology with a FaCT deducer, and to confirm the consistency of ontology by converting DAM_OIL to SHIQ Description Logic[11]. OntoEdit, developed by Ontoprise in Germany based on DAML+OIL language, provides user interface but is difficult to use. In the hierarchy constructed in tree plot, user can reorganize concepts by using copy and paste functions[12].

Ontology provides effective andflexible resources for communication between human being and computer by combining with terminology that has linguistic concept system. Ontology materializes more significant knowledge system in a limited theme than thesaurus does. Further more, it is hardly expected to get higher efficiency in information system with terminology and thesaurus due to ambiguous semantic structure, since their formality of definition and compliance of machine are far below that ontology. Ontology with clarity and diversity of definition on conceptual access and relationships between concepts heightens recapitulation rate and exactness in information searching, and facilitates quality formation.

It also allows an intellectual searching rather than a keyword matching access, and makes it easy to expand its quality. Semantic description being provided by ontology improves quality services in information searching[13].

Construction of ontology is necessary to meet the recent requirements in $\mathrm{u}$-Health field, which can support searching technology on integrated healthcare contents personalized by a patient, a nursery person or a user. Therefore, this study aims to design and construct a model of ontology for healthcare contents[1]. 


\section{Constructing Food Ontology Model}

\subsection{Proposed Food Ontology Model}

The prime information needed for healthcare is about food, nutrients, products, and those related contents. Dietary and food prescription play an important role in healthcare. Hence, this study builds up an ontology model focusing at food among them.

Food ontology defines classes, properties, and relationships by basic elements. Each class describes unique characteristics in hierarchy and defines them by their properties. A class can define a relationship with other class and have a disjoint relationship that does not cross with each other. If defining beverage, fruit, meat, and sea produce classes as a disjoint relationship, it can be induced that any instance of beverage can not be an instance of fruit, meat, and sea produce.

Property, the term used in ontology, means the unique characteristics that a class has, for example, when a class defines a bicycle, property indicates those information on its frame, handle bars, wheels, and gears. Food ontology class defines properties of daily intake in maximum, recommended, and minimum quantity to provide a patient or a user with information necessary for self-administration. It can be utilized in monitoring function for food recommendation or dietary record.

Considering that adult diseases, the biggest enemy to the present society that emphasizes health, are caused by various environmental factors and $90 \%$ of those environmental factors that trigger adult diseases are associated with dietary habits, we can understand the significant influence of dietary on prevention and treatment of adult diseases[14]. we have to precisely examine Food for correct dietary and evaluate the contemporary dietary habits with this knowledge, then we can contribute to the more advanced healthcare system by providing a personalized information that effects on health[15][16].

\subsection{Design the Food Ontology Model}

This study intends to design ontology model focusing on Food in the $\mathrm{u}$-Health service. Conceptual drawing of Food ontology is shown on Fig.1. In Fig.1, the most upper concept is Food and it divides into the lower concepts like beverages, fruits, and meats. When designing its hierarchy with this concept in detail, it can be constructed that has Food at the most upper class with 13 lower classes under it.

The main lower classes can be defined as beverage, fruits, meats, egg-products, grain-products, milk-products, nut-products, oils-fats-products, seafood, soups-sauces- mics, special nutrition-products, sugar-products and vegetables.

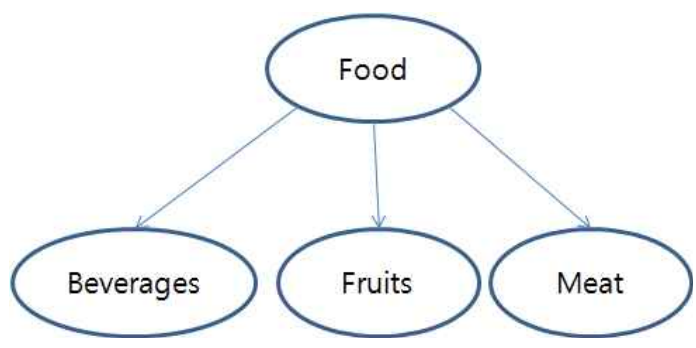

$<$ Fig. 1 $>$ Food Class

This hierarchy is based on a single succession rule and is able to accept any additional constraints related with a class.

\subsection{Constructing the Food Ontology}

Food ontology is constructed with Food class at the most upper class and 13 lower classes under it. Food Class and the next lower class are shown on the Fig. 2. Protege 4.0.2. is used for construction of the ontology. 


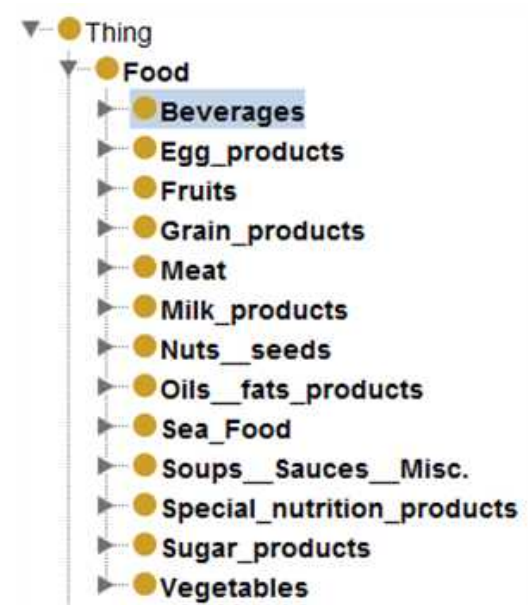

$<$ Fig. 2> Food and next lower Class

\subsection{Definition of the Food Class}

Properties of the beverage class, the lower class of the Food Class, is defines in quantity and calorie, and is shown on Fig. 3.

Fig. 3 illustrates many classes classified into Food, and in order to define the properties of the beverage class among them, the properties of calorie and quantity is defined as on Fig.4, by selecting the beverage class.

And the definition of disjoint constraints in the beverage class, the lower class of Food Class, is shown on Fig. 5.

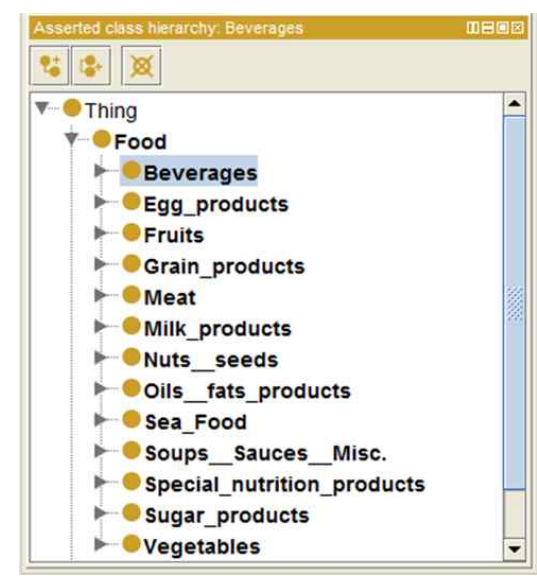

$<$ Fig. 3> Definition of property in Food Class

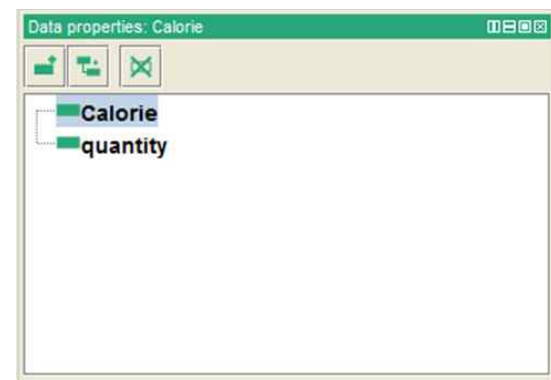

$<$ Fig. $4>$ Definition of property Beverages

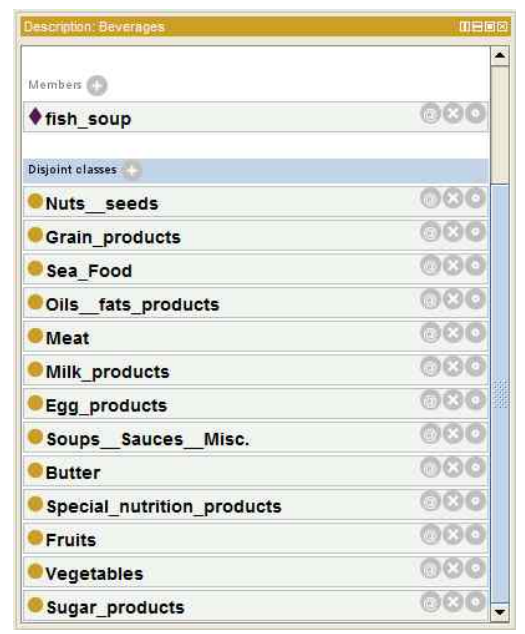

$<$ Fig. 5> Definition of disjointness in beverage

The relationship of beverage class, the lower class of Food Class, with other classes is appeared on Fig. 6. Alcoholic-mixed-drinks class is the lower class of beverage class, and beers-and-maltbeverages class is also belonged to beverage class. Here, the class information, the disjointWith relationship of beverage class, can be recognized.

Fig. 7. shows the description information of Alcoholic-mixed-drinks, the lower class of the beverage class. To define a personalized item in a class is possible and it is shown on Fig. 8. Description information can be defined at the right side panel by selecting Alcoholic-mixed-drinks in the left class browser.

In the Description, Equivalent class or Super class can be defined additionally and Members are additionally defined.

It is a description panel of the Alcoholic-mixed- 
drinks class and defines potatoes into Members.

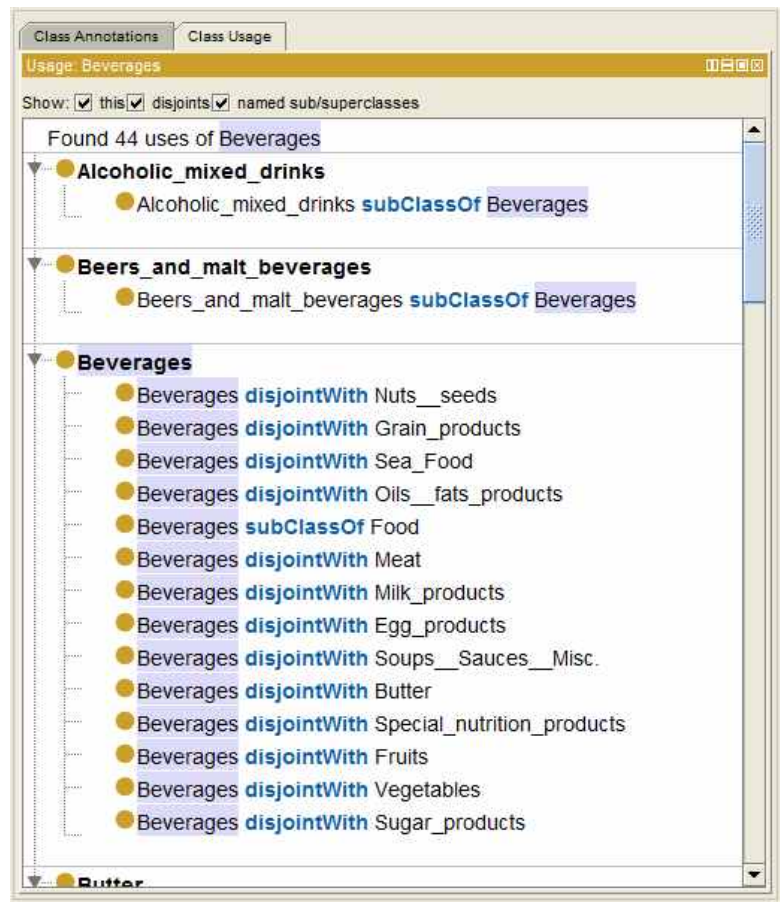

$<$ Fig. 6> Relationship of Beverages Class with Other Class

With individual information of the Alcoholic ${ }^{-}$ mixed-drinksclass, extravirgin_olive_oil, fish_soup, grain_sour, meat_poultry_soup, new_potatoes, olive_oil, olive_oil_with_vitamin, potatoes can be defined.

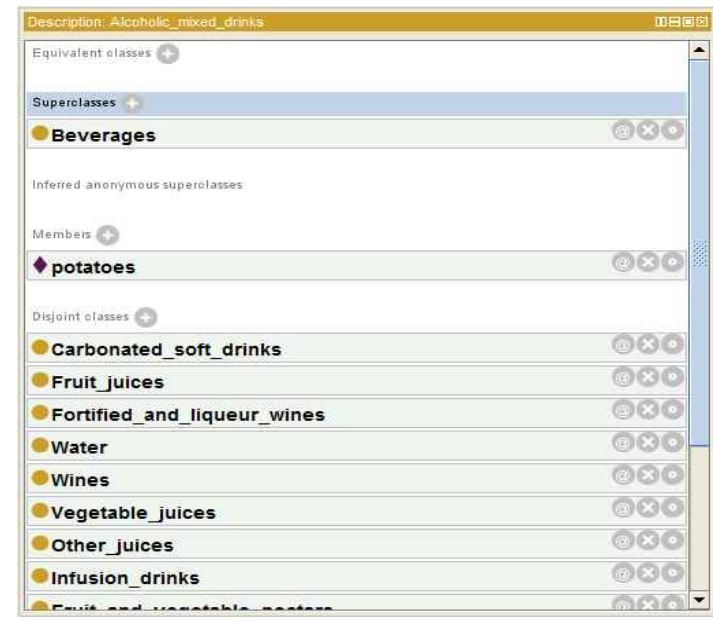

$<$ Fig. 7> Alcoholic_mixed_drinks Description
This study explains from the view of nutrition and healthcare of Food ontology, and the entire hierarchy of Food ontology is shown on Table 1. Food, the most upper Root class, is defined and 13 lower classes like the Beverages and the Egg-products are defined, then total 67 third lower classes are defined upon defining each second class, like 5 classes from the Beverage class such as the Alcoholic-mixed-drinks, 5 classes from the Eggproducts class such as the Chicken-eggs.

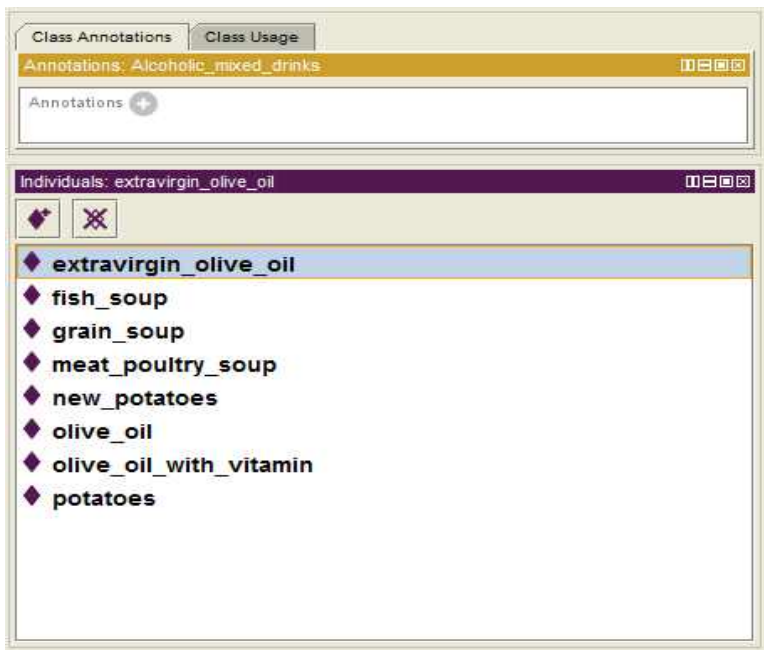

$<$ Fig. 8> Individuals Defined for the class

$<$ Table 1> Main Hierarchy in Food ontology

\begin{tabular}{|c|c|c|}
\hline Root & 2nd Class & 3rd Class \\
\hline \multirow{17}{*}{ Food } & Beverages & Alcohlic_mixed_drinks \\
\hline & & Beers_and malt_beverages \\
\hline & & carbonated_soft_drink \\
\hline & & ciders_perries_drinks \\
\hline & & Dilution_drinks \\
\hline & Egg_products & Chicken_eggs \\
\hline & & Duck_eggs \\
\hline & & Egg_dishes \\
\hline & & Goose_eggs \\
\hline & & Ostrich_eggs \\
\hline & Frutis & Berries \\
\hline & & Citrus_fruit \\
\hline & & Fruit_mixture \\
\hline & & Fruit_products \\
\hline & & Malaceous_fruit \\
\hline & Grain_products & Barley_basic_products \\
\hline & & Basic_products_cereals \\
\hline
\end{tabular}




\begin{tabular}{|c|c|}
\hline & Bread_products \\
\hline & Breakfast_cereals \\
\hline & Corn_basic_products \\
\hline \multirow[t]{5}{*}{ Meat } & Beef_carcass_meat \\
\hline & Birds_other \\
\hline & Chicken \\
\hline & Kindney \\
\hline & Liver \\
\hline \multirow[t]{5}{*}{ Milk_products } & Blue_cheese \\
\hline & Cream \\
\hline & Fresh_cheese \\
\hline & Hard_cheese \\
\hline & Ices \\
\hline \multirow[t]{4}{*}{ Nuts_seeds } & Nut_and_seed_products \\
\hline & Nuts \\
\hline & Pulse_products \\
\hline & Pulses \\
\hline & Seeds_and_kernels \\
\hline \multirow[t]{5}{*}{ Oils_fats_products } & Animal_fat \\
\hline & Butter \\
\hline & Compound_fats_and_oil \\
\hline & Fat_spread \\
\hline & Marine_oil \\
\hline \multirow[t]{5}{*}{ Sea_Food } & Amphibinans \\
\hline & Canned_fish \\
\hline & Clipeiforemes \\
\hline & Crustaceans \\
\hline & Cypriniformes \\
\hline \multirow[t]{5}{*}{ Soups_Saues_Misc } & Baking_goods \\
\hline & Chutney \\
\hline & Condiments \\
\hline & Dissert_sauces \\
\hline & Dips \\
\hline \multirow[t]{5}{*}{ Special_nutrition } & Baby_foods \\
\hline & Enteral_foods \\
\hline & Fat_modified_foods \\
\hline & High_energy_products \\
\hline & Low_energy_products \\
\hline \multirow[t]{6}{*}{ Sugar_products } & Chochlate_coated_bars \\
\hline & Chocolate_products \\
\hline & Honey \\
\hline & Jams \\
\hline & Jelly \\
\hline & Other_sugar \\
\hline \multirow[t]{5}{*}{ Vegetables } & Brassicas \\
\hline & Edible_fungi \\
\hline & Fruit_vegetables \\
\hline & Leaf_Vegetables \\
\hline & Onion_family_vegetables \\
\hline & Rtto_vegetables \\
\hline
\end{tabular}

\section{Modeling the Search System using Food ontology}

As a search example using Food ontology, a scenario can be assumed that searches daily maximum intake quantity before checking out choosing a can of coke at the beverage corner during shopping at a super-market The properties of 'hasMaxAmount', 'hasMedAmount', and 'hasMinAmount'can be defined additionally on the constructed ontology as on the Fig. 9, and the property value can be set up for each item by using them.

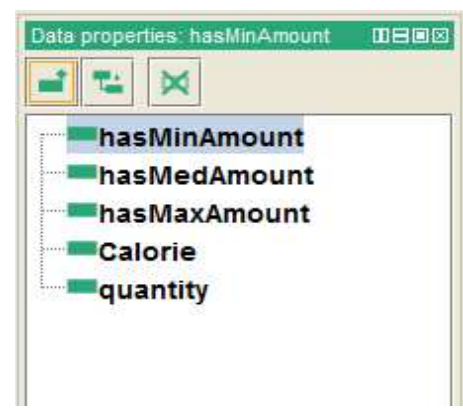

$<$ Fig. 9> Definition of Data properties

By clicking Add properties button, additionally defines properties of 'hasMaxAmount', 'hasMedAmount', 'hasMinAmount', 'Calorie', and 'quantity'.

Additionally defines item coke in 'Individual', and defines 'hasMinAmount' as '0', and 'hasMaxAmount' as 230. This can be utilized when searching with a mobile device available for Web or network. For this, it can be searched by using Query tool in the Protege frame as on Fig. 11. If a user doubts on a can of coke upon picking it up at the beverage corner, he/she can either input bar code or make scan search before checking out when shopping at a supermarket, and through this process, the user can find the daily Minimum Intake quantity and daily maximum intake quantity. Displaying the changed features of the user's health condition comparing both with that of before drinking and that of after drinking helps the user in making 
favorable decision.

Like this, the personalized healthcare system providing the user's experience contributes to self-administration of those chronicle patients and nursing people to whom correct dietary habits based on the professional medical information are essential.

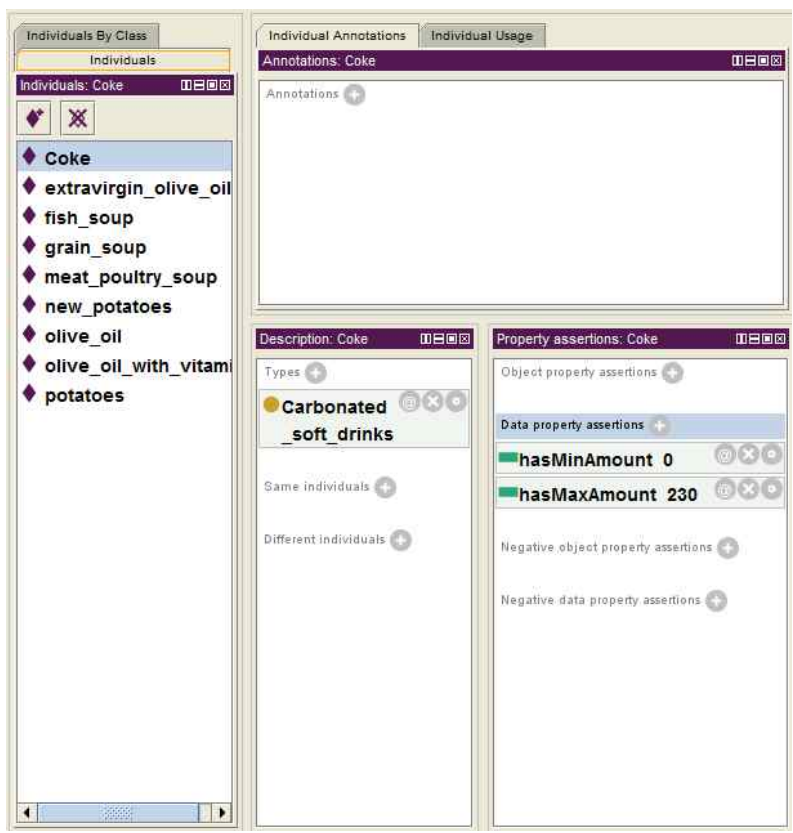

$<$ Fig. 10> Individuals Defined for the coke

For such a Food information constructed in ontology, computer can automatically interpret and deduce its contents. This kind of search function controls a user's diet and daily intake quantity, being engaged with the healthcare solution, and provides the personalized healthcare information like prescription on overall physical exercises, and enables positive recommendation or prohibition function.

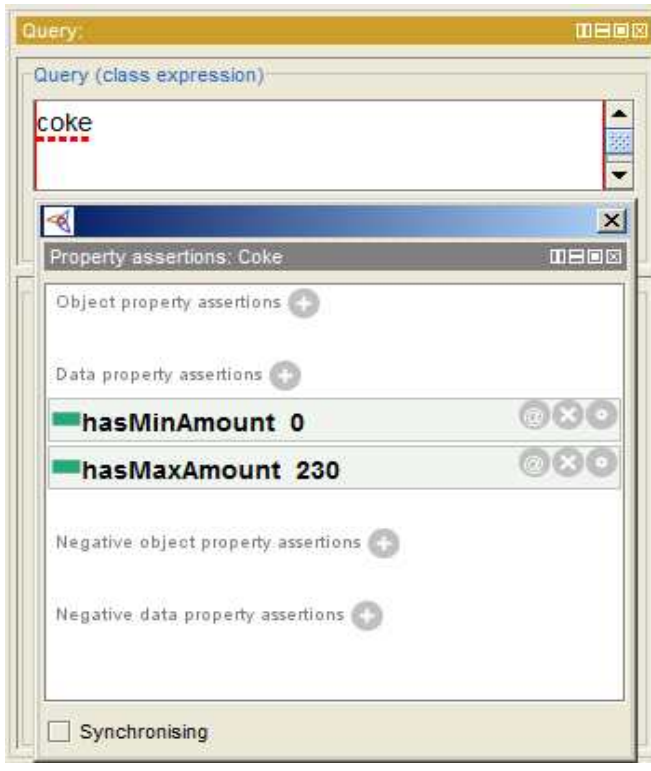

$<$ Fig. 11 > Query for coke

A user can search contents lists and inquire its detailed information by mapping contents information and Food ontology information in a healthcare contents control system with Food ontology. The healthcare contents control system controls various contents such as healthcare related multimedia, Web pages, and documents, and provides these services to users.

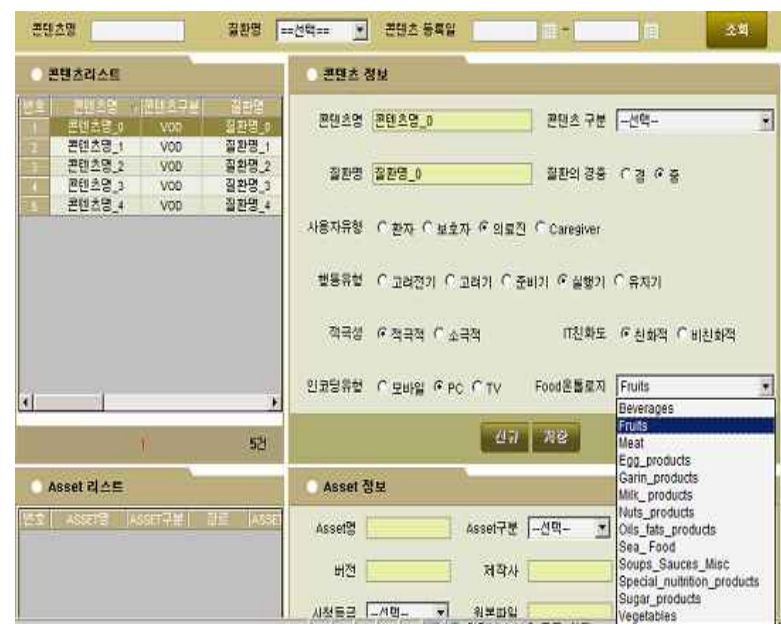

$<$ Fig. 12> Contents Search Test on implemented Food ontology system

When registering a Food related contents, usercan 
register the relevant contents, Food ontology class and mapping information. With this, user can inquire the list by entering names of contents and disease and registration date of the contents when searching contents. For Food related contents, user can inquire the class name, description, property values of the daily maximum intake, the daily recommended intake ,and the daily minimum intake, and the values of constraints in Food ontology by using mapping information with Food ontology.

Like this, the healthcare contents control system incorporates meta information and file information as well as additionally constructed information in Food ontology, and realizes the added services to healthcare according to these information. Food ontology being oriented to openness has another significance as it does not end up at simple construction, but enhances its applicability by incorporating into and engaging with other systems.

\section{Conclusion}

This paper aims to construct ontology that allows Semantic search to make quick and easy search for healthcare contents information which a patient or his/her family or a user needs under ubiquitous environment. When utilizing ontology, user can make a search that reflects requirements of inquiry by processing the inquired word semantically. Further, it can process those ever-changing information related with food by semantic units by converting various information on the Web or a database into ontology.

Also, information by semantic unit can be described in various types as it can be processed as an individual object. Any event information acquired from ontology can be produced in a natural language type or information related with Food can be displayed in the types that user can easily understand by expressing them in graphic type It suggests a model by realizing Food ontology based on Protege, and can be referred as a user-oriented contents control system that is easy to add new knowledge and modify it based on concept and is applicable to dynamic information environment.

Considering above results, it is very important to enhance quantity and quality of the personalized healthcare with self-care contents being tailored to a patient or a user by searching quickly and correctly the contents information which a patient or a user needs out of mountainous web contents data. Various researches should be sought in order to lead a more healthy life by triggering interest of a patient and his/her family or other users and by utilizing it directly for personal healthcare.

\section{References}

[1] Luke, Chen, Biswas, "A Survey of Semantic Similarity Methods for Ontology Based Information Retrieval", ICMLC, $20102^{\text {nd }}$ Int'l $^{\prime}$ Conference, pp. 297-301, 2010.

[2] Cho Young-seon, Baek Hyun-gi, and Kim Jeong-gyoum, "Design and construction of Q\&A system based on Ontology about nutrients for a middle school Manual training and household curriculum", Dissertation by the Korea Association of Computer Education, Vol. 11, No. 3, pp. 317-327, 2007.

[3] Park Ji-hyun, "Estimation and verification of workflow changes based the enterprise Ontology", Thesis for M.A degree, Ulsan University, 2007.

[4] Jiehan Zhou, Koivisto, Niemela, "A Survey on Semantic Web Services and a Case Study", CSCWD '06. $10^{\text {th }}$ Int'l Conference, IEEE, pp. 1-7, 2006.

[5] Wallace A. P., and Ana M. C., "An Ontology Based-Approach for Semantic Search in Portals", Proc. of the 15th Int'l Workshop on Database and Expert Systems Applications, pp.127-131, 2004.

[6] Studer R., Benjamins V., and Fensel D. "Knowledge engineering, principles and methods", 
Data and Knowledge Engineering, pp.161-197, 1998.

[7] Gwon Hyeok-cheol, "Possibility and limitation of Semantic Web", Knowledge \& Information Infra, 2004.

[8] Kim won-pil, Kim Jeong-ho, "Study on development of Ontology Tool", 2008.

[9] Shin Dong-Young, Lee Byung-Mun, "Flexible Model of the Sequence Numbering depending on Sampling periods for the Security of Medical Information", Journal of The Korean Institute of Information Technology, Vol. 10, No. 1, pp. 127-138, 2012.

[10] http://kaon.semanticweb.org/

[11] Robert Stevens, and Chris Wroe, "Building Ontologies in DAML+OIL", Comparative and Functional Genomics, Vol. 4, pp.133-141, 2003.

[12] http://www.ontoknowledge.org/tools/ontoed it.shtml

[13] Park Eun-jun, "Model to retrieve professional knowledge using Ontology from Semantic Web". 2003.

[14] Sung Nak-eung, "Dietary treatment for chronicle patients", The Korean Association of Chronic Disease Management.

[15] Yoo Kee-Dong, Hwang Hyun-Seok, "Ontologybased Implementation of the Process-Oriented Knoweldge Map", Journal of the Korea Industrial Information Systems Research, Vol.17, No.4, pp. 87-97. 2012.

[16] Ha Dong-One, Lee Chang-Jo, "Study on the direction of serious contents design for training skills in U-healthcare: Focused on elderly learners", Journal of the Korea Industrial Information Systems Research, Vol.15, No.3, pp. 23-32. 2010.

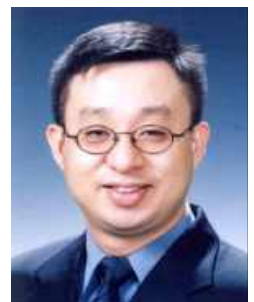

이 병 문 (Byung Mun Lee)

- 정회원

- 동국대학교 전자계산학과 공학사

- 서강대학교 컴퓨터공학과 공학석사

- 인천대학교 컴퓨터공학과 공학박사

- 가천대학교 IT대학/인터랙티브미디어학과 교수

- 관심분야 : 유헬스, 의료정보, 사물기반인터넷

논 문 접 수 일. 2012년 08월 31일 1차수정 완료일 . 2012년 10월 15일 2차수정 완료일 . 2012년 11월 12일 게 재 확 정 일 2012년 11월 13일 